\title{
Job insecurity among nurses, nursing technicians and nursing aides in public hospitals*
}

\author{
Precarização do trabalho de enfermeiras, técnicas e auxiliares \\ de enfermagem nos hospitais públicos \\ Precarización del trabajo de enfermeras, técnicas y auxiliares \\ de enfermería en los hospitales públicos
}

Tatiane Araújo-dos-Santos ${ }^{1}$, Handerson Silva-Santos ${ }^{1}$, Maria Navegantes da Silva ${ }^{2}$, Ana Carla Carvalho Coelho ${ }^{1}$, Cláudia Geovana da Silva Pires ${ }^{1}$, Cristina Maria Meira de Melo ${ }^{1}$

How to cite this article:

Araújo-dos-Santos T, Silva-Santos H, Silva MN, Coelho ACC, Pires CGS, Melo CMM. Job insecurity among nurses, nursing technicians and nursing aides in public hospitals. Rev Esc Enferm USP. 2018;52:e03411. DOI: http://dx.doi.org/10.1590/S1980-220X2017050503411

* Extracted from the thesis: "Precarização do trabalho em enfermagem nos hospitais públicos: 2013-2017”, Programa de Pós-

Graduação, Escola de Enfermagem,

Universidade Federal da Bahia, 2018.

${ }^{1}$ Universidade Federal da Bahia, Escola de Enfermagem, Salvador, Bahia, Brazil.

${ }^{2}$ Universidade Federal da Bahia, Escola de Enfermagem, Programa de Pós-Graduacão em Enfermagem, Salvador, Bahia, Brazil.

\begin{abstract}
Objective: To identify the contribution of all the dimensions involved in job insecurity among nursing professionals in Brazilian state public hospitals. Method: This was a quantitative descriptive study conducted between March 2015 and February 2016, with nurses, nursing technicians and nursing aides. The data were analyzed using exploratory factor analysis. Results: The sample consisted of 265 nurses ( $n=161$ with job security and $n=104$ outsourced) and 810 nursing technicians and nursing aides ( $n=597$ with job security and $n=213$ outsourced). Among the nurses, "Working conditions" accounted for $46.8 \%$ of their job insecurity. Among nursing technicians and nursing aides "intensity of work due to work process organization" best explained the construct of job insecurity (51.2\%). Conclusion: Job insecurity is expressed differently depending on the type of nursing professional. The difference in the distribution of the dimensions showed that job insecurity is related to the hierarchical position of each nursing professional in the technical division of nursing work and the role of each professional in the work process.
\end{abstract}

DESCRIPTORS

Nursing; Working Conditions; Hospitals, Public; Public Sector; Unified Health System. 


\section{INTRODUCTION}

Job insecurity refers to a political regime based on the instability and permanent insecurity of workers, submitting them to further exploration. In Brazil, job insecurity among public servants was driven by changes resulting from the Reform of State Apparatus. During the 1990s and early 2000s, job insecurity in public service emerged through lack of wage correction for almost all workers; the implementation and expansion of different types of remuneration; increased outsourcing of workers; and intolerance and authoritarianism of employers in their relationship with public sector unions ${ }^{(1-3)}$.

Public servants had an impact during the administration of former president Fernando Henrique Cardoso, creating the idea in the public eye of excess public servants, with privileges in terms of career and wages ${ }^{(4)}$. During the administrations of Luís Inácio Lula da Silva and Dilma Rousseff 2002-2012 and 2012-2016, respectively, of the Worker's Party (PT) changes were made to the pension regulations for these workers - their right to full retirement pay was eliminated, outsourcing was expanded, and wage policies went unchanged ${ }^{(5)}$.

In 2017, the government alliance of President Michel Temer, who took over as President after a legal-parliamentary-media coup in 2016, increasing the impact on public servants and approving, in the Constitution and Justice Commission in October 2017, Bill 116, which regulates the dismissal of public servants by subjective criteria, and Temporary Decree 805/2017, which postponed or canceled the wage increase scheduled for 2018. Then, once again, public servants had an effect from the economic and political crisis in the country.

Considering that in the health sector, the government is the greatest employer of nurses, nursing technicians and nursing aides, these workers are also affected by job insecurity $^{(6)}$. The types of job insecurity in nursing include type of employment relationship, instability, income, working hours, the right to free association, and work conditions ${ }^{(7)}$, which affect the health and quality of life of these workers, predisposing them to physical exhaustion and psychological issues ${ }^{(8)}$.

In addition, nursing professionals are the largest professional group in the health field. In hospitals, they carry out continuous and uninterrupted patient monitoring and surveillance activities, coordinating the work of other health professionals and ensuring care delivery. With job insecurity, nursing professionals are exposed to greater suffering, as they are unable to do everything that is best for patients.

Job insecurity in public health services directly affects the population. It limits access to services and exposes hospitalized patients to risks during care provision, since poor work conditions demand improvised actions that negatively affect patient safety ${ }^{(8)}$.

An analysis of this topic in the main databases of the Virtual Health Library (VHL) showed incipient scientific production about the relationship between job insecurity and public health services. Thus, it is important to investigate job insecurity in public services to understand its complexity and implications in nursing. Therefore, a better understanding of job insecurity among nurses, nursing technicians, and nursing aides provides a window into how job insecurity has infiltrated public health services.

Considering the above, the purpose of this study was to identify the contribution of all dimensions involved in job insecurity among nursing professionals in Brazilian state public hospitals.

\section{METHOD}

This was a quantitative descriptive study conducted at 15 public hospitals directly managed by the Health Department of the State of Bahia (SESAB - Secretaria da Saúde do Estado da Babia) and seven hospitals indirectly managed by SESAB, which accepted to participate in the study.

Stata Statistical Software Release 11 and the information from hospital medical records were used to estimate the size of the study population. As the prevalence of studied phenomena was unknown $(\mathrm{p}=0.50)$, a sampling error of $3 \%$ $(d=0.03)$ and $95 \%$ confidence level $(\alpha=0.05)$ were considered. The sample of the nursing professionals consisted of 265 nurses ( $n=161$ with job security and $n=104$ outsourced) and 810 nursing technicians and nursing aides $(n=597$ with job security and $n=213$ outsourced).

Data collection was performed between March 2015 and February 2016, in various care sectors, including outpatient clinics, wards and high-complexity units. A 96-item questionnaire was used to collect data, validated by the researchers via pre-testing. The researchers approached and invited nursing workers to participate at their respective sectors during their work hours. The inclusion criteria were: nurses, nursing technicians, and nursing aides who had worked for at least 6 months at the health organization and who were able to answer the questions. Nursing professionals who had been working for less than 6 months at the health organization or who had participated in the study's development were excluded.

Exploratory factor analysis (EFA) was used in data analysis to identify latent variables (factors) with relevant explanatory power for the object of study. The main reasons for using EFA are: to validate the results of an evaluation and to develop a theory, because this technique analyzes the construct and the synthesis of its relations, resulting in factors that can be used in other analyses ${ }^{(9)}$.

Considering that the construct of job insecurity comprises several factors and the absence of studies in nursing that identifies such factors, EFA was used to identify how the dimensions contribute to nursing job insecurity.

This process was carried out in two steps: 1 . As per the study conducted by Druck ${ }^{(10)}$, the dimensions of job insecurity were defined by distributing all 96 variables among these dimensions and building a factorization matrix; 2. The matrix was submitted to factorization according to professional category and type of employment 
relationship. The Kaiser-Meyer-Olkin (KMO) test was performed, with an overall score of 0.8307 for nurses and 0.8794 for nursing technicians and nursing aides. The scree test was used to extract factors. Next, factorial rotation was performed, with the cut-off point at 0.40 . Two forms of factorial rotation were tested: orthogonal rotation (matrix of independent factors) with varimax, and oblique rotation (matrix of dependent factors) with promax, using 4, 5 and 6 factors, respectively. The decision to use a matrix with 4,5 or 6 factors and whether they should be dependent or independent was made by the researchers.

After the factorization process, of the 96 initial variables, 32 variables remained in the matrix for nurses and 33 in the matrix for nursing technicians and nursing aides, distributed among the following dimensions of job insecurity: Working conditions; intensity of work due to work process organization; intensity of work due to multiple jobs; intensity of work due to extended working hours; work process management; elimination of employment rights.

To evaluate the contribution of every dimension to the construct of "job insecurity," eigenvalue, difference, proportion of explanation, cumulative and uniqueness were calculated. These matrices were debated and evaluated at six separate moments with experts in the field of nursing work, job insecurity, epidemiology and statistics.

Cronbach's alpha coefficient was used to validate the internal consistency of all variables and dimensions of job insecurity, with an overall score of 0.8822 for nurses and 0.8839 for nursing technicians and nursing aides, which shows a strong correlation between the answers ${ }^{(11)}$.

This study fulfilled the ethical requirements of Resolution 466/12 issued by the Brazilian National Health Council and was analyzed and approved by the Research Ethics Committee of the Nursing School at the Federal University of Bahia, protocol 398.772/2013.

\section{RESULTS}

Most study participants were female (nurses: $90.1 \%$, technicians and nursing aides: $86.9 \%$ ), were aged 31 to 55 years (nurses: 76.9\%; technicians and nursing aides: $82.9 \%$ ), had 6-15 years of experience in the profession (nurses: 79.8\%; technicians and nursing aides: $48.1 \%$ ), and self-declared as black in terms of ethnicity (nurses: $83.9 \%$, technicians and nursing aides: 91.3\%).
Figure 1 illustrates the results of the scree test. A sharp reduction can be observed at factor 5 , with a decreasing curve of variance, indicating the elimination of the other factors.

Table 1 shows the dimensions of the job insecurity matrix for nurses. "Working conditions" accounts for $46.8 \%$ of job insecurity. The dimensions related to "intensity of work" account for $29.3 \%$, and "work process management", $11.7 \%$.

The eigenvalue for a given factor measures the variance in all the variables which is accounted for by that factor only factors with a value greater than 1 should be extracted. The "Working conditions" dimension presented the greatest contribution to variance (Table 1).

The matrix for job insecurity among nursing technicians and nursing aides (Table 2) shows that "Intensity of work due to work process organization" was the dimension that most contributed to explaining the construct of job insecurity (51.2\%), and its eigenvalue presented the highest shared variance.

Chart 1 and Chart 2 show the factor matrixes for job insecurity among nurses, nursing technicians and nursing aides, respectively. In both matrixes, the categories "work process management' and "intensity of work due to multiple jobs" presented the variables with the greatest factor loading.

"Intensity of work due to work process organization" was the only dimension whose variables presented negative factor loading, which means they contribute to reducing "intensity of work due to work process organization".

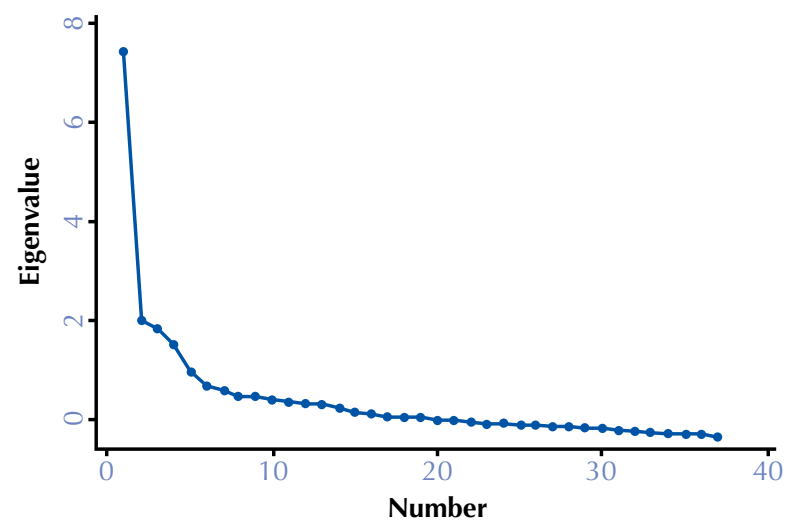

Figure 1 - Scree test for the extraction of factors - Salvador, Bahia, Brazil, 2017.

Table 1 - Eigenvalue, difference, proportion of explanation, and cumulative value of the dimensions of the matrix for job insecurity of Nurses - Salvador, Bahia, Brazil, 2017.

\begin{tabular}{|c|c|c|c|c|}
\hline Dimensions & Eigenvalue & Difference & Proportion & Cumulative \\
\hline Working conditions & 7.44065 & 5.37495 & 46.8 & 0.4676 \\
\hline Intensity of work due to work process organization & 2.06570 & 0.20992 & 13.0 & 0.5974 \\
\hline Work process management & 1.85578 & 0.28626 & 11.7 & 0.7140 \\
\hline Intensity of work due to multiple jobs & 1.56952 & 0.54297 & 9.9 & 0.8126 \\
\hline Intensity due to reduced rest periods & 1.02655 & 0.30754 & 6.4 & 0.8771 \\
\hline
\end{tabular}


Table 2 - Eigenvalue, difference, proportion of explanation, and cumulative value of the dimensions of the matrix for job insecurity of Nursing technicians and nursing aides - Salvador, BA, Brazil, 2017.

\begin{tabular}{lcccc}
\hline Dimensions & Eigenvalue & Difference & Proportion & Cumulative \\
\hline Intensity of work due to work process organization & 7.75547 & 5.87457 & 51.2 & 0.5198 \\
Working conditions & 1.88090 & 0.20807 & 12.6 & 0.6459 \\
Work process management & 1.67283 & 0.45960 & 11.2 & 0.7580 \\
Intensity of work due to multiple jobs & 1.21322 & 0.17761 & 0.1 & 0.8393 \\
Elimination of employment rights & 1.03561 & 0.13155 & 6.9 & 0.9087 \\
\hline
\end{tabular}

Chart 1 - Factor matrix - job intensity of nurses by dimensions, variables and factor loading - Salvador, BA, Brazil, 2017.

\begin{tabular}{|c|c|c|}
\hline Dimensions & Variables & Factor loading \\
\hline \multirow{11}{*}{ Working conditions } & Participates in continuing education activities & 0.6808 \\
\hline & Feels they are aware of the risks to which they are exposed & 0.5962 \\
\hline & The work in this place makes nurses feel satisfied & 0.5809 \\
\hline & Participates in meetings to organize the activities & 0.5557 \\
\hline & Nurse uses Standard Operation Procedures (SOP) & 0.5484 \\
\hline & Equipment and furniture items are ergonomic & 0.5481 \\
\hline & Working conditions are suitable to patient profile & 0.5480 \\
\hline & They are informed of the outcomes of care provided & 0.5233 \\
\hline & Personal Protective Equipment (PPE) items are available & 0.4476 \\
\hline & Feels socially recognized for their work & 0.4160 \\
\hline & Immediate boss is concerned about well-being of subordinates & 0.4009 \\
\hline \multirow{11}{*}{$\begin{array}{l}\text { Intensity of work due to } \\
\text { work process organization }\end{array}$} & Time pressure at work & 0.6779 \\
\hline & Work pace & 0.6651 \\
\hline & Work requires more than nurses are able to do & 0.6052 \\
\hline & Care provided to more patients than nurses can handle & 0.5700 \\
\hline & Takes on multiple tasks due to staff shortage & 0.5494 \\
\hline & Supervises more workers than the nurse can handle & 0.4307 \\
\hline & Tasks are interrupted before nurses can complete them & 0.4140 \\
\hline & Repetitive movements while performing work tasks & 0.4039 \\
\hline & Rest period during the working hours & -0.4589 \\
\hline & Work allows nurses to perform activities and achieve goals without rushing & -0.4946 \\
\hline & Meals without rushing during the working hours & -0.5517 \\
\hline \multirow{6}{*}{ Work process management } & Presence of conflicts & 0.7967 \\
\hline & Conflict impacts how activities are performed & 0.7722 \\
\hline & Has experienced embarrassment at work & 0.4974 \\
\hline & Feels pressured by superior while performing tasks & 0.4935 \\
\hline & Has been a victim of violence at work & 0.4352 \\
\hline & Has been a victim of discrimination at work & 0.4114 \\
\hline \multirow{2}{*}{ Intensity of work due to multiple jobs } & Number of jobs & 0.9148 \\
\hline & Weekly hours of work at other jobs & 0.9138 \\
\hline \multirow{2}{*}{ Intensity due to reduced rest periods } & Rest periods during night shift & 0.5149 \\
\hline & Daily hours of work & 0.4908 \\
\hline
\end{tabular}


Chart 2 - Factor matrix - job intensity of nursing technicians and nursing aides by dimensions, variables and factor loading - Salvador, BA, Brazil, 2017.

\begin{tabular}{|c|c|c|}
\hline Dimensions & Variables & Factor loading \\
\hline \multirow{7}{*}{$\begin{array}{l}\text { Intensity of work due } \\
\text { to work process organization }\end{array}$} & Work requires more than the nursing professional can do & 0.6696 \\
\hline & Assumes multiple assignments due to staff shortage & 0.6156 \\
\hline & Care provided to more patients than the nursing professional can handle & 0.5844 \\
\hline & Time pressure at work & 0.5518 \\
\hline & Work rhythm & 0.5251 \\
\hline & Performs activities that are not his/her assignment & 0.4804 \\
\hline & Performs activities with which he/she does not agree & 0.4551 \\
\hline \multirow{6}{*}{$\begin{array}{l}\text { Intensity of work due to } \\
\text { work process organization }\end{array}$} & Feels pressured by the boss while performing the task & 0.4542 \\
\hline & Performs activities for which he/she is not qualified & 0.4328 \\
\hline & Tasks are interrupted before he/she can conclude them & 0.4323 \\
\hline & Rest periods during the working hours & -0.4510 \\
\hline & Work allows nurses to perform activities and achieve goals without rushing & -0.4863 \\
\hline & Meals without rushing during the working hours & -0.5046 \\
\hline \multirow{13}{*}{ Working conditions } & Working conditions are suitable to patient profile & 0.6350 \\
\hline & Equipment and furniture items are ergonomic & 0.5958 \\
\hline & Feels he/she is aware of the risks to which he/she is exposed & 0.5725 \\
\hline & Participates in activities of continuing education & 0.5123 \\
\hline & PPE items are available & 0.5097 \\
\hline & Proper material for consumption is available & 0.5076 \\
\hline & Participates in meetings to organize the activities & 0.4948 \\
\hline & The work in this place makes the nursing professional satisfied & 0.4775 \\
\hline & $\mathrm{He} / \mathrm{she}$ is informed of the results from care provided & 0.4765 \\
\hline & Immediate boss is concerned about well-being of subordinates & 0.4616 \\
\hline & Employment rights are respected & 0.4498 \\
\hline & Nursing professional uses SOP & 0.4440 \\
\hline & Feels socially recognized due to his/her work. & 0.4186 \\
\hline \multirow{2}{*}{ Intensity of work due to multiple jobs } & Number of jobs & 0.9282 \\
\hline & Weekly working hours of other jobs & 0.9272 \\
\hline \multirow{3}{*}{ Work process management } & Existence of a conflict & 0.6020 \\
\hline & Conflict impacts the way the activities are performed & 0.5642 \\
\hline & Has experienced embarrassment at work & 0.4711 \\
\hline \multirow{2}{*}{ Elimination of employment rights } & Career planning is available & 0.5683 \\
\hline & Has been benefitted by career planning & 0.5673 \\
\hline
\end{tabular}

\section{DISCUSSION}

Since the 1990s, the Brazilian government has adopted neoliberal prerogatives, such as the reduction of public expenditures, not fulfilling its constitutional duty to ensure the right to health to the Brazilian population. The government cannot refrain from providing health services; however, by adopting such neoliberal prerogatives, it causes job insecurity in public services and among public workforce, for instance, in the form of pay gaps, infrequent selection processes, and expansion of outsourcing ${ }^{(1,8)}$. In this context, the dimensions of job insecurity in nursing work indicate government errors and omissions in the maintenance of health services and the exploration to which nurses, nursing technicians and nursing aides are subjected.

The dimensions of job insecurity described in Tables 1 and 2 were distributed differently among nursing professionals. For nurses, "Work conditions" is the dimension that most contributes to job insecurity (46.8\%), while for nursing technicians and nursing aides, "Intensity of work due to work process organization" (51.2\%). 
The place occupied by middle management nurses in a work process of care and management nature ${ }^{(12)}$ demands working conditions such as infrastructure, administrative and medical-hospital inputs, sizing and qualification of nursing staff, availability of information including patient clinical information, access to other professionals such as physicians, work relations, among others.

In this work process, nurses have to deal with the pressure exerted by the nursing staff themselves, other health workers, patients and leaders of the organizations to mobilize and articulate the resources required in care provision.

For nursing technicians and nursing aides, who in the work process assume care activities and tasks, the dimension of "Intensity of work due to work process organization" is significant to explain job insecurity. These workers highlight work requires more than they can perform, as described in Chart 2. In addition, in the hierarchy created by the technical distribution of nursing work, technicians and nursing aides are pressured by nurses, to whom they are subordinated in the activities. The variable of "Assumes multiple assignments due to staff shortage" (Chart 2) indicates undersized nursing staff, which also implies this dimension. Other studies also highlighted the intensity of work as a relevant factor in job insecurity in nursing ${ }^{(13-14)}$.

In addition to performing their own tasks, nursing technicians and nursing aides, who represent most professionals in health workforce, also help other professionals, particularly physicians. Therefore, these workers receive demands from three groups during their work process: from nurses, other health professionals, and patients, who refer to them to fulfill their immediate needs.

However, another factor should be highlighted which moves away from the Taylorist logic of nursing work, but increases the intensity of such work in the context of job insecurity: the nursing work, like any other health work, is active and relational, because the object of health work, that is, the needs expressed by patients, is changeable.

Then, although tasks are performed in a fragmented way, and there is pressure to achieve goals (particularly in outsourced hospitals, a legacy of Toyotism), patients conduct part of the health work process according to their needs, demanding more or less actions of nursing professionals.

Studies on nursing work in Brazil, Argentina and Germany found similar results regarding the elements of job insecurity: inadequacies in physical and material structure, high workload, undersized staff, greater work intensity, and uncorrected wages that force nursing professionals" to have more than one job ${ }^{(8,15-17)}$.

The nurses, nursing technicians and nursing aides who participated in this study work in public hospitals that do not always ensure proper organizational or material working conditions for the provision of health services and services, as indicated in several studies ${ }^{(17-19)}$.

The hospitals with direct management of SESAB do not have local autonomy to replace or purchase materials or hire employees, limiting the performance of their managers and offering poor conditions to staff. It occurs in the context of the work process organization based on the tripartite of
Neoliberal State - job insecurity - Toyotism, with deterioration of public services as a strategy to promote privatization of these services.

Two dimensions that are not shared among nursing workers are also highlighted: "Intensity of work due to extra hours", which is relevant for nurses, and "Elimination of employment rights", relevant for nursing technicians and nursing aides.

The dimension of "Intensity of work due to extra hours" includes variables related to proper rest period and place and daily working hours. This study found this dimension is relevant only for nurses due to its care and management nature, which generates excessive activities and tasks. Also, there is no definition of a rest period and place in the hospitals analyzed in this study, which can generate deeper stress on nursing professionals, even if the daily work day does not exceed the limit defined in the employment agreement.

The dimension of "Elimination of employment rights" includes variables related to wage and career. These variables contribute to job insecurity among nursing technicians and nursing aides, given these workers receive the lowest salaries in nursing ${ }^{(6)}$. The explanation is given by the social and technical division of work and the characteristics that make up the value of the workforce of nursing technicians and nursing aides. They have shorter training and perform manual work. Then, the perception of the value of such workforce is affected by two factors that contribute to its reduction, and reduction of the price paid to these professionals ${ }^{(20-21)}$.

The study limitation referred to its long period of data collection due to the conditions of the research field.

\section{CONCLUSION}

The results indicate job insecurity in public health services and in nursing work; however, job insecurity was expressed differently by the nursing professionals.

The nurses, nursing technicians and nursing aides are subject to intensity of work, poor working conditions, and models of work process management that increase the exploration of their work. The dimensions of job insecurity analyzed in this study affect nursing professionals and the clinical practice, since they prevent or limit the care provided to patients, considering that some minimum working conditions are not fulfilled. In addition, the intensity of work due to multiple jobs subjects workers to physical, mental and psychological fatigue, which may contribute to errors in care provision.

The differences in the distribution of job insecurity dimensions show that it is related to the hierarchical position of each worker in the technical division of work in Nursing. The differences observed among nurses and nesting technicians and nursing aides show the continuity of work division, a legacy of Taylorist work organization. This division enhances job insecurity in nursing and explains the differences among women workers.

This study may be extended to other states of Brazil so its results may be compared to the results of future investigations. 


\section{RESUMO}

Objetivo: Identificar a contribuição das dimensões que compõem a precarização do trabalho em Enfermagem nos hospitais públicos estaduais. Método: Estudo quantitativo, descritivo, realizado entre março de 2015 e fevereiro de 2016, com enfermeiras, técnicas e auxiliares de. Os dados foram analisados por meio da Análise Fatorial Exploratória. Resultados: A amostra constituiu-se de 265 enfermeiras ( $n=161$ estatutárias e $n=104$ terceirizadas) e 810 técnicas e auxiliares de Enfermagem ( $n=597$ estatutárias e n=213 terceirizadas). Para as enfermeiras, a dimensão Condições de trabalho contribuiu com $46,8 \%$ para a explicação da precarização. Entre as técnicas e auxiliares, a Intensidade do trabalho pela organização do seu processo foi a dimensão que mais explicou o constructo precarização $(51,2 \%)$. Conclusão: A precarização do trabalho se expressa de forma distinta entre as trabalhadoras. A diferença na distribuição das dimensões demonstrou que a precarização guarda relação com a posição hierárquica de cada trabalhadora na divisão técnica do trabalho em Enfermagem e com o lugar ocupado no processo de trabalho.

\section{DESCRITORES}

Enfermagem; Condições de Trabalho; Hospitais Públicos; Setor Público; Sistema Único de Saúde.

\section{RESUMEN}

Objetivo: Identificar la contribución de las dimensiones que componen la precarización laboral en Enfermería en los hospitales públicos estaduales. Método: Estudio cuantitativo, descriptivo, realizado entre marzo de 2015 y febrero de 2016, con enfermeras, técnicas y auxiliares de enfermería. Los datos fueron analizados mediante el Análisis Factorial Exploratorio. Resultados: La muestra se constituyó de 265 enfermeras ( $n=161$ empleadas estatutarias y n=104 tercerizadas) y 810 técnicas y auxiliares de Enfermería ( $n=597$ empleadas estatutarias y n=213 tercerizadas). Para las enfermeras, la dimensión Condiciones laborales contribuyó en el 46,8\% para la explicación de la precarización. Entre las técnicas y auxiliares, la Intensidad laboral por la organización de su proceso fue la dimensión que más explicó el constructo precarización (51,2\%). Conclusión: La precarización laboral se expresa de forma distinta entre las trabajadoras. La diferencia en la distribución de las dimensiones demostró que la precarización guarda relación con la posición jerárquica de cada trabajadora en la división técnica del trabajo en Enfermería y con el lugar ocupado en el proceso laboral.

\section{DESCRIPTORES}

Enfermería; Condiciones de Trabajo; Hospitales Públicos; Sector Público; Sistema Único de Salud.

\section{REFERENCES}

1. Druck G. A terceirização na saúde pública: formas diversas de precarização do trabalho. Trab Educ Saúde. 2016;14(Supl. 1):15-43. DOI: http://dx.doi.org/10.15990/1981-7746-sol00023.

2. Antunes R, Druck G. A terceirização sem limites: a precarização do trabalho como regra. Social em Questão [Internet]. 2015 [citado 2017 set. 7];34:19-40. Disponível em: http://www.cressrn.org.br/files/arquivos/Sm4618UP754c17102374.pdf.

3. Bourdieu P. Contrafogos: táticas para enfrentar a invasão neoliberal. Rio de Janeiro: Zahar; 1998.

4. Gomes D, Silva CLB, Sória S. Condições e relações de trabalho no serviço público: o caso do governo Lula. Rev Sociol Polít [Internet]. 2012 [citado 2017 set. 20]; 20(42):167-181. Available from: http://www.scielo.br/pdf/rsocp/v20n42/12.

5. Pessoa RS. Disputa política e agenda administrativa: do governo FHC à gestão Lula-Dilma. Arquivo Jurídico [Internet]. 2015 [citado 2017 ago. 01]; 2(1):61-81. Disponível em: http://www.ojs.ufpi.br/index.php/raj/article/view/4507

6. Machado MH, Santos MR, Oliveira E, Wermelinger M, Vieira M, Lemos W, et al. Condições de trabalho da Enfermagem. Enferm Foco [Internet]. 2016 [cited 2017 abr. 03];6(1/4):79-90. Available from: http://revista.portalcofen.gov.br/index.php/Enfermagem/article/ view/695/305.

7. Melo CMM, Carvalho CA, Silva LA, Leal JAL, Santos TA, Santos HS. Força de trabalho da enfermeira em serviços estaduais com gestão direta: revelando a precarização. Esc Anna Nery. 2016; 20(3):e20160067. DOI: http://dx.doi.org/10.5935/1414-8145.20160067

8. Souza NVDO, Gonçalves FGA, Pires AS, David HMSL. Influência do neoliberalismo na organização e processo de trabalho hospitalar de Enfermagem. Rev Bras Enferm. 2017;70(5):912-9. DOI: http://dx.doi.org/10.1590/0034-7167-2016-0092

9. Sousa LMM, Marques-Vieira CMA, Carvalho MLR, Veludo F, José HMG. Fidelidade e validade na construção e adequação de instrumentos de medida. Enformação [Internet]. 2015 [cited 2017 Set 30];25-32.

10. Druck G. Trabalho, precarização e resistências: novos e velhos desafios? Cad CRH. 2011;24(n.spe 1):37-57. DOI: http://dx.doi.org/10.1590/ S0103-49792011000400004.

11. Hora HRM, Monteiro GTR, Arica J. Confiabilidade em questionários para qualidade: um estudo com o Coeficiente Alfa de Cronbach. Produto Produção. 2010;11(2):85-103. DOI: http://dx.doi.org/10.22456/1983-8026.9321.

12. Melo CMM, Santos TA, Leal JAL. Processo de trabalho assistencial-gerencial da enfermeira. In: Vale EG, Peruzzo SA, Felli VEA, organizadores. PROENF - Programa de Atualização em Enfermagem: gestão: Ciclo 4. Porto Alegre: Artmed; 2015. p. 45-75.

13. Tomazoni A, Rocha PK, Ribeiro MB, Serapião LS, Souza S, Manzo BF. Segurança do paciente na percepção da Enfermagem e medicina em unidades de terapia intensiva neonatal. Rev Gaúcha Enferm. 2017;38(1):e64996. DOI: http://dx.doi.org/10.1590/19831447.2017.01.64996

14. Pereira SS, Teixeira CAB, Reisdorfer E, Vieira MV, Gherardi-Donato ECS, Cardoso L. A relação entre estressores ocupacionais e estratégias de enfrentamento em profissionais de nivel tecnico de Enfermagem. Texto Contexto Enferm. 2016;25(4): e2920014. DOI: http://dx.doi. org/10.1590/0104-07072016002920014.

15. Aspiazu E. Las condiciones laborales de las y los enfermeros en Argentina: entre la profesionalización y la precariedad del cuidado en la salud. Trabajo Soc [Internet]. 2017[citado 2017 nov. 22]; (28):11-35. Disponible en: http://www.scielo.org.ar/scielo.php?script=sci_ arttext\&pid=S1514-68712017000100002\&lng=es\&tlng=es.

16. Cramer Henning, Pohlabeln Hermann, Habermann Monika. Factors causing or influencing nursing errors as perceived by nurses: findings of a cross-sectional study in German nursing homes and hospitals. J Public Health. 2013;21:145-53. DOI: http://dx.doi.org/10.1007/ s10389-012-0527-6. 
17. Brasil. Tribunal de Contas da União. Relatório Sistêmico de Fiscalização/Saúde [Internet]. Brasilia; 2013 [citado 2017 nov. 03]. Disponível em: https://portal.tcu.gov.br/biblioteca-digital/relatorio-sistemico-de-fiscalizacao-saude.htm

18. Braga LM, Torres LM, Ferreira VM. Condição de trabalho e fazer em Enfermagem. R Enferm UFJF [Internet]. 2015 [citado 2017 dez. 01];1(1):55-63. Disponível em: https://Enfermagem.ufjf.emnuvens.com.br/Enfermagem/article/view/13/8.

19. Marx K. O capital: crítica da economia política: Livro I: o processo de produção do capital. São Paulo: Boitempo; 2013.

20. Santos TA, Melo CMM, Leal JAL, Rodrigues VG, Santos HS. The value nurse workforce. Int J Nurs. 2016;3(1):9-37. 